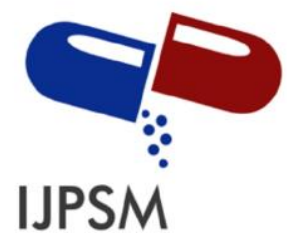

Sisi Mustika et al, Int. Journal of Pharmaceutical Sciences and Medicine (IJPSM), Vol.6 Issue. 9, September- 2021, pg. 1-7

ISSN: 2519-9889

Impact Factor: 3.426

\title{
The Potential Anti-Inflammatory Effects of Brucea javanica (L.) Merr.
}

\author{
Sisi Mustika ${ }^{1}$; Sri Oktavia ${ }^{1}$; Ifora Ifora ${ }^{1}$ * \\ ${ }^{1}$ Departemen of Pharmacology and Clinical Pharmacy, School of Pharmaceutical Science, Padang (STIFARM \\ Padang), West Sumatera, Indonesia, 25147 \\ For Correspondence: Tel. +(62) 85266031448, Email: iforafo03@gmail.com \\ DOI: 10.47760/ijpsm.2021.v06i09.001
}

\begin{abstract}
Inflammation is the initial response to acute and chronic tissue damage, which is characterized by redness, swelling, heat, and pain. Natural products derived from plants have specific pharmacological activity and minimal side effects. Brucea javanica is a plant that has an anti-inflammatory effect, this plant contains alkaloid and flavonoid compounds. Flavonoids have the ability to block cyclooxygenase and lipoxygenase while alkaloids as an anti-inflammatory are thought to work by inhibiting prostaglandin $\mathrm{H} 2 \mathrm{PGH} 2$ which is an inflammatory mediator. From the data obtained, there is no complete literature that reviews its use as an anti-inflammatory. The search databases used are as follows: Pubmed, ScienceDirect, and Google Scholar to study the anti-inflammatory activity of Brucea javanica. All recent research articles were published between 2010 to 2021. Based on eligibility, 4 studies were included in this study, consisting of 2 In vivo studies and 2 In vitro and In vivo studies. A series of pharmacological studies have reported that Brucea javanica can block the Nf-kB signaling pathway and decrease the production of inflammatory mediators. It has been reported to be able to inhibit the production of NO, PGE2, TNF-, IL-1 $\beta$, IL-18IL-23, COX-2, NF- $\kappa B$, IFN- $\gamma$, IL-6, the levels of MPO (Myeloperoxidase), reducing the edema and induce the production of the anti-inflammatory cytokine (IL-4, IL-10 and TGF- $\beta$ ). Brucea javanica also markedly activates Nrf2 expression suppressing the inflammatory response-mediated NLRP3 and NF- $\kappa B$ activation. In addition, the elevated mRNA expression of MMP-1, MMP-3 and RAGE was remarkably inhibited by Brucea javanica, while the mRNA expression of PPAR- $\gamma$ was significantly enhanced. In vitro and in vivo studies strongly indicate that Brucea javanica has the potential as an anti-inflammatory.
\end{abstract}

Keywords: Anti-inflammatory, Cyclooxygenase-2, Brucea javanica

\section{Introduction}

Inflammation is caused by the immune system becomes activated in response to various stimuli. The immune system is a highly complex and evolutionarily optimized defence system with both cellular and humoral components. The course of the inflammatory response is influenced by immune conditions and local tissue adaptations, which may be influenced by individual genetic factors [1], [2]. Inflammation is the natural response of body tissues and organs after trauma, whether acute or chronic, acute infection, or tissue damage mediated by an acute crisis. It is positive and spontaneous so it is useful in response to acute injury or pathogens invading the body [3][4]. Acute inflammation is usually a reversible response involving leakage of plasma components and emigration (extravasation) of leukocytes to the extravascular [5]. Chronic 


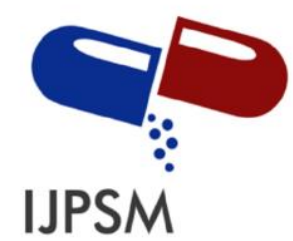

Sisi Mustika et al, Int. Journal of Pharmaceutical Sciences and Medicine (IJPSM), Vol.6 Issue. 9, September- 2021, pg. 1-7

ISSN: 2519-9889

Impact Factor: $\mathbf{3 . 4 2 6}$

inflammation generally develops as part of the sequence of cellular events following acute inflammation. The cell types that characterize what pathologists term chronic inflammation primarily including lymphocytes, macrophages, and plasma cells [6][7].

The types of NSAIDs that are widely circulated in drugstores are non-selective NSAIDs of the diclofenac group, metamysol, piroxicam, paracetamol, acetosal, indomethacin, phenylbutazone. These nonselective NSAIDs can bind to all COX-2 receptors. This type is relatively cheap, so it is bought more to deal with pain complaints, on the other hand, COX-2 selective NSAIDs are more expensive so people prefer to buy non-selective NSAIDs [8]. Like many other drugs, however, NSAIDs have a wide range of side effects, including cardiovascular (CV) and gastrointestinal (GI) events, high blood pressure, renal toxicity, and aggravation of congestive heart failure[9]-[11]. Natural products of plant origin have received attention for their specific pharmacological activity and minimal side effects[12], [13]. Among them, phenolic compounds, terpenoids, and alkaloids show an extraordinary spectrum of therapeutic activity due to their anticancer, antiinflammatory, antithrombotic, muscle relaxant, and memory-enhancing effects [14]. Other inflammatory mediators observed were prostaglandin E2 and nitric oxide. Prostaglandin E2 (PGE2) is an arachidonic acid derivative produced by the action of COX1 and COX2 cyclooxygenases [15].

One of the plants that have various pharmacological activity was Brucea javanica L. [16]. Brucea javanica contains alkaloids, Brucein D, quassinoid, brusatol, [17], [18]. A study conducted by Ma et al. reported the oleic and linoleic acid content of Brucea javanica oil which has been shown by animal and human studies to inhibit tumor formation [19]. Another study repeorted that Brucea javanica exhibited antitumor activity, anticholesterol, antihyperglycemic[18], [20], [21]. Tumors, hypercholesterolemia and diabetes are pathologically associated with inflammatory events [22]-[24]. Based on this data, Brucea javanica held the promising potential to be further developed into a natural anti-inflammatory agent. However, currently, a small portion of Brucea Javanica Leave has been tested to ensure anti-inflammatory activity. From the data obtained, there is no complete literature available regarding its use as an anti-inflammatory. Therefore, it is important to develop herbal knowledge that is useful for future drug discovery efforts, the aim of this review is to gather evidence from the extensive literature of studies reporting the anti-inflammatory activity of Brucea Javanica.

\section{Data Collection}

The present review was performed using the databases as follows: Google Scholar, ScienceDirect, PubMed. In this review, the search terms used were "Anti-inflammatory", "Inflammatory", and "Ailanthus gracilis Salisb." using the publication from 2010 to 2021. Only accessible online articles in English or Indonesian were reviewed. All abstracts and full-text articles were collected, examined, summarized, and conclusions made accordingly. The taxonomy of plants has been verified from the "The Plant List" database (www.theplantlist.org).

\section{Results and Discussion}

The anti-inflammatory activity of Brucea javanica has been demonstrated in vitro and in vivo. A total of 4 studies were included in this paper based on our eligibility criteria. This study used various extracts, which consist of plant parts (leaves, seeds, and Brucea javanica oil). The anti-inflammatory properties of Brucea javanica are summarized in Table I. 


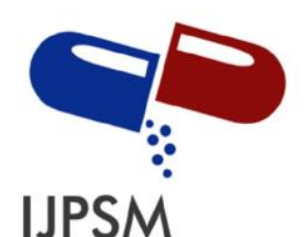

Sisi Mustika et al, Int. Journal of Pharmaceutical Sciences and Medicine (IJPSM), Vol.6 Issue. 9, September- 2021, pg. 1-7

ISSN: 2519-9889

Impact Factor: 3.426

TABLE 1. Summary of anti-inflammatory properties of Brucea javanica (In vitro and In vivo studies)

\begin{tabular}{|c|c|c|c|c|c|c|c|}
\hline $\begin{array}{c}\text { Type of } \\
\text { extract or } \\
\text { Formulation }\end{array}$ & $\begin{array}{c}\text { Plant } \\
\text { part and } \\
\text { Source } \\
\text { used for } \\
\text { studies }\end{array}$ & $\begin{array}{c}\text { Dose/ } \\
\text { Concentration }\end{array}$ & $\begin{array}{c}\text { Experimental } \\
\text { Model }\end{array}$ & $\begin{array}{c}\text { Animal } \\
\text { and } \\
\text { disease } \\
\text { models }\end{array}$ & $\begin{array}{l}\text { Pharmacologi } \\
\text { cal effects } \\
\text { (Reported } \\
\text { activity) }\end{array}$ & Country & Ref.(s) \\
\hline $\begin{array}{c}\text { Brucea } \\
\text { javanica oil } \\
\text { emulsion }\end{array}$ & Oil & $\begin{array}{l}0.35,0.7 \text { and } 1.4 \\
\mathrm{~g} / \mathrm{kg}\end{array}$ & $\begin{array}{l}\text { Inflammatory } \\
\text { cytokine } \\
\text { productions in } \\
\text { TNBS- } \\
\text { induced colitis } \\
\text { in rats. }\end{array}$ & $\begin{array}{l}\text { Male } \\
\text { Sprague } \\
\text { Dawley } \\
\text { rats (In } \\
\text { vivo) }\end{array}$ & $\begin{array}{c}\text { Brucea } \\
\text { javanica oil } \\
\text { showed anti- } \\
\text { inflammatory. }\end{array}$ & China & [25] \\
\hline $\begin{array}{l}\text { Etil acetat } \\
\text { fraction }\end{array}$ & Seeds & $\begin{array}{l}1.25,2.5,5,10 \\
\mathrm{~g} / \mathrm{ml} \text { (in vitro) } \\
5,25 \mathrm{mg} / \mathrm{kg} \text { (In } \\
\text { vivo) }\end{array}$ & $\begin{array}{c}\text { LPS- } \\
\text { stimulated } \\
\text { RAW264.7 } \\
\text { macrophage } \\
\text { model (In } \\
\text { vitro) } \\
\text { Carrageenan- } \\
\text { Induced paw } \\
\text { edema (In } \\
\text { Vivo) }\end{array}$ & $\begin{array}{c}\text { RAW } \\
264.7 \\
\text { macrophag } \\
\text { e cells (In } \\
\text { vitro) } \\
\text { ICR male } \\
\text { mice (In } \\
\text { vivo) }\end{array}$ & $\begin{array}{l}\text { Ethyl acetate } \\
\text { fraction of } \\
\text { Brucea } \\
\text { javanica } \\
\text { showed that } \\
\text { anti- } \\
\text { inflammatory. }\end{array}$ & China & [26] \\
\hline $\begin{array}{l}\text { Isolated } \\
\text { compound } \\
\text { (Brusatol) }\end{array}$ & Brusatol & $\begin{array}{l}25 \text { to } 100 \mathrm{nM} \\
\text { (In Vitro) } \\
(0.25,0.5,1.0 \\
\mathrm{mg} / \mathrm{kg}) \\
\text { (In vivo) }\end{array}$ & $\begin{array}{c}\text { MacrohpageR } \\
\text { AW } 264.7 \\
\text { cells( In Vitro) } \\
\text { Induced colitis } \\
\text { rat and } \\
\text { lipopolysaccha } \\
\text { ride (In vivo) }\end{array}$ & $\begin{array}{l}\text { Macrohpag } \\
\text { eRAW } \\
264.7 \text { (In } \\
\text { vitro) ) } \\
\text { Male } \\
\text { Sprague } \\
\text { Dawley } \\
\text { rats (In } \\
\text { vivo) }\end{array}$ & $\begin{array}{c}\text { Brusatol } \\
\text { exhibited anti- } \\
\text { inflammatory } \\
\text { activity. }\end{array}$ & China & [27] \\
\hline $\begin{array}{l}\text { Ethanol } \\
\text { extract }\end{array}$ & Leaves & $250,500 \mathrm{mg} / \mathrm{kg}$ & $\begin{array}{l}\text { Carrageenan- } \\
\text { Induced paw } \\
\text { edema(In } \\
\text { Vivo) }\end{array}$ & $\begin{array}{l}\text { White } \\
\text { Male Rat } \\
\text { (In vivo) }\end{array}$ & $\begin{array}{l}\text { The ethanolic } \\
\text { extract } \\
\text { showed } \\
\text { significant } \\
\text { anti- } \\
\text { inflammatory } \\
\text { activity. }\end{array}$ & Indonesia & [28] \\
\hline
\end{tabular}




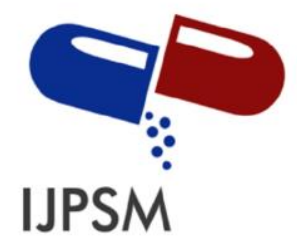

\section{Sisi Mustika et al, Int. Journal of Pharmaceutical Sciences and Medicine (IJPSM), Vol.6 Issue. 9, September- 2021, pg. 1-7}

ISSN: 2519-9889

Impact Factor: 3.426

The databases used for this review include PubMed, Google Scholar, and ScienceDirect. The search results from the database used are 4 articles that are considered relevant to the research. Based on all of this research, the oil from Brucea Javanica is the most commonly utilized formulation, both as a pure oil and as a suspension. Oil, leaves, seeds, and the type of active ingredient identified (brusatol) from Brucea javanica were all used as plant parts or dosage forms in all of the articles analyzed.

The follow-up investigation cunducted by Huang et al. endeavoured to illuminate the potential benefit of Brucea javanica oil emulsion on 2, 4, 6-trinitrobenzene sulfonic acid (TNBS)-induced Crohn's disease (CD) in rats and decipher the mechanism of action. This study illustrated that Brucea javanica oil emulsion treatment significantly decreased the levels of MPO (Myeloperoxidase) and pro-inflammatory cytokines (TNF- $\alpha$, IL- $1 \beta$, IL-6, IL-17, IL-23 and IFN- $\gamma$ ), and increased the levels of anti-inflammatory cytokines (IL-4, IL-10 and TGF$\beta$ ) as compared with the model group. In addition, the elevated mRNA expression of MMP-1, MMP-3 and RAGE induced by TNBS was remarkably inhibited by Brucea javanica oil emulsion, while the mRNA expression of PPAR- $\gamma$ was significantly enhanced. Furthermore, the activation of TLR4/NF- $\kappa$ B signaling pathway was significantly inhibited by Brucea javanica oil emulsion treatment when compared with that of TNBS-treated rats. The study suggested that Brucea javanica oil emulsion exerted superior therapeutic effect in treating TNBS-induced colitis in rats. The protective effect of Brucea javanica oil emulsion may involve the inhibition of the TLR4/NF- $\kappa B$-mediated inflammatory responses at a dose $(0.7 \mathrm{~g} / \mathrm{kg})$ [25]. Previous investigations showed that Brucea javanica has some oleic acid and linoleic acid that exerts an antiinflammatory effect by modulating the production of inflammatory mediators such as IL-1 $\beta$, IL-6, IL-17, IL-23 and IFN- $\gamma$ ) which may contribute to the anti-inflammatory effect of Brucea javanica oil [29], [30]. The results showed that the ethyl acetate extract of Brucea Javanica oil emulsion significantly decreased the production of inflammatory mediators [25].

A study conducted by Yang et al. reported that the ethyl acetate fraction of Brucea javanica seeds exhibited anti-inflammatory activity. Ethyl acetate from Brucea javanica seeds was able to modulate the production of inflammatory mediators NO, PGE2, TNF-, IL-1 $\beta$, IL-6, and IL-10 in RAW 264.7 macrophages. Effect of Ethyl acetate from Brucea javanica seeds on NO and PGE2 production as determined by ELISA kit on carrageenan-induced leg edema at a dose of $25 \mathrm{mg} / \mathrm{kg}$ showed inhibition of activity greater than $5 \mathrm{mg} / \mathrm{kg}$ and Ethyl Acetate Brucea Javanica suppressed edema was tested internally. In vitro showed remarkable antiinflammatory activity of Ethyl Acetate Brucea Javanica through inhibition of NO, PGE2, TNF- $\alpha$, IL-1 $\beta$ and IL-6 production of inflammatory mediators and induction of anti-inflammatory cytokine IL-10 production. The results obtained in vitro and in vivo suggest that the possible anti-inflammatory effect of Ethyl Acetate Brucea Javanica could be attributed to the inhibition of the production of pro-inflammatory mediators NO, PGE2, TNF-, IL-1 $\beta$ and IL-6 and to increase the production of cytokine anti-inflammatory IL-10. Brucea javanica seeds may thus prove beneficial in the treatment of inflammatory diseases [26].

A study conducted by Zhou et al. reported that the compound fraction of Brusatol isolated from Brucea javanica exhibited anti-inflammatory activity. Effect of Brusatol on the production of proinflammatory molecules in LPS-stimulated RAW 264.7 (Lipopolysaccharide) cells. The effect of Brusatol on inflammatory cytokine production was measured by ELISA. Treatment with Brusatol $(0.5$ and $1.0 \mathrm{mg} / \mathrm{kg})$ increased the production of TGF- $\beta$ and IL- 4 and inhibited the accumulation of IL-1 $\beta$ and IL-18. The results showed that Brusatol mainly inhibited the production of TNF- $\alpha$, pro-IL-1 $\beta$, PGE2 and NO and suppressed the $\mathrm{NF}-\kappa \mathrm{B}$ signaling pathway in Lipopolysaccharide-stimulated macrophages. Brusatol treatment also increased levels of TGF- $\beta$ and IL-4 decreased levels of IL- $1 \beta$ and IL-18 content. Furthermore, Brusatol also significantly activated Nrf2 expression suppressing the inflammatory activation of NLRP3 and inflammatory responsemediated NF- $\kappa$ B. Brusatol may have the potential to be further developed into a promising therapeutic agent for the treatment of colitis [27].

A study conducted by Ifora et al. reported that the ethanolic extract of Brucea javanica leaves exhibited anti-inflammatory activity. There are two groups in this study, namely negative control and positive control. Anti-inflammatory activity on male white rats was proven by the increased inhibition of inflammation 


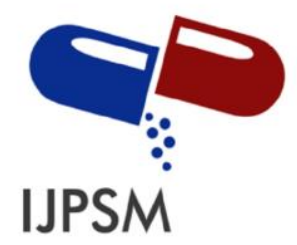

Sisi Mustika et al, Int. Journal of Pharmaceutical Sciences and Medicine (IJPSM), Vol.6 Issue. 9, September- 2021, pg. 1-7

ISSN: 2519-9889

Impact Factor: 3.426

in the carrageenan induction test in rat paws. In the measurement of inflammation at a dose of $500 \mathrm{mg} / \mathrm{kg} \mathrm{BW}$ and $250 \mathrm{mg} / \mathrm{kg} \mathrm{BW}$, it implies that these two doses have almost the same activity in reducing the volume of inflammation. The inhibition test of the cyclooxygenase 2 (COX-2) enzyme of the ethanol extract of malur (Brucea javanica (L.) Merr.) showed that there was no significant inhibition of the COX-2 enzyme at a dose of $250 \mathrm{mg} / \mathrm{kg} \mathrm{BW}$. In this study, the results showed that the $250 \mathrm{mg}$ dose was not significant in inhibiting COX-2, while at the $500 \mathrm{mg}$ dose the results were significant in inhibiting COX-2 [28].

\section{Conclusion and Future Prospects}

Brucea javanica plants exhibited anti-inflammatory activity through inhibition the levels of MPO (Myeloperoxidase), COX-2, PGE2, NO, TNF- $\alpha$, IL-1 $\beta$, IL-6, IL-17, IL-18, IL-23, IFN- $\gamma$, suppression of TLR4/NF- $\kappa$ B \& NLRP3-mediated inflammatory responses, regulation of Nrf2-mediated oxidative stress and increased the levels of anti-inflammatory cytokines (IL-4, IL-10 and TGF- $\beta$ ). In addition, the elevated mRNA expression of MMP-1, MMP-3 and RAGE was remarkably inhibited by Brucea javanica, while the mRNA expression of PPAR- $\gamma$ was significantly enhanced. Furthermore, Brucea javanica was reported to be effective in reducing the edema. Further research is needed to better understand the role of these metabolites in antiinflammatory actions and may contribute to the production of new anti-inflammatory drugs in the future. Furthermore, future research on the anti-inflammatory activity of Brucea javanica should include sources and specifications for the plant extracts used. To ascertain the anti-inflammatory activity of Brucea javanica, the methods and conditions used in vitro and in vivo must be validated.

\section{Acknowledgements}

The authors are grateful to all colleagues at The Departement of Pharmacology and Clinical Pharmacy, School of Pharmaceutical Science Padang (STIFARM Padang), for helpful discussions.

\section{Conflict of Interest}

The authors declare that they have no conflicts of interest.

\section{References}

[1]. C. Sahlmann and P. Ströbel, "Pathophysiologie der Entzündung," Inst. für Pathol. Univ. Göttingen, pp. 1-6, 2016.

[2]. R. Medzhitov, “Overview Essay Inflammation 2010 : New Adventures of an Old Flame,” pp. 771776, 2010, doi: 10.1016/j.cell.2010.03.006.

[3]. D. Kumar, “Clinical Molecular Medicine," Clin. Mol. Med., 2020, doi: 10.1016/b978-0-12-8093566.00033-2.

[4]. J. N. Fullerton and D. W. Gilroy, "Resolution of inflammation: a new therapeutic frontier," Nat. Publ. Gr., vol. 15, no. 8, pp. 551-567, 2016, doi: 10.1038/nrd.2016.39.

[5]. F. S. Zetoune, C. N. Serhan, and P. A. Ward, Inflammatory Disorders «s, no. July. Elsevier Inc., 2014.

[6]. R. L. Kradin, "Understanding Pulmonary PhatoLogy," Underst. Pulm. PhatoLogy, no. 21-36, 2017.

[7]. D. N. Granger and E. Senchenkova, Inflammation and the Microcirculation, vol. 2, no. 1. 2010.

[8]. M. Soleha, A. Isnawati, N. Fitri, R. Adelina, H. T. Soblia, and W. Winarsih, "Profil Penggunaan Obat Antiinflamasi Nonstreoid di Indonesia," J. Kefarmasian Indones., vol. 8, no. 2, pp. 109-117, 2018, doi: $10.22435 / j k i . v 8 i 2.316$.

[9]. C. Sostres, C. J. Gargallo, and A. Lanas, "Nonsteroidal anti-inflammatory drugs and upper and lower gastrointestinal mucosal damage," Arthritis Res. Ther., vol. 15, no. SUPPL 3, pp. 1-8, 2013, doi: 10.1186/ar4175.

[10].C. Sostres, C. J. Gargallo, M. T. Arroyo, and A. Lanas, "Adverse effects of non-steroidal anti- 


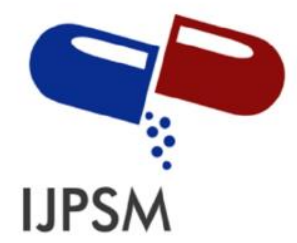

Sisi Mustika et al, Int. Journal of Pharmaceutical Sciences and Medicine (IJPSM), Vol.6 Issue. 9, September- 2021, pg. 1-7

ISSN: 2519-9889

Impact Factor: 3.426

inflammatory drugs (NSAIDs, aspirin and coxibs) on upper gastrointestinal tract," Best Pract. Res. Clin. Gastroenterol., vol. 24, no. 2, pp. 121-132, 2010, doi: 10.1016/j.bpg.2009.11.005.

[11].S. Harirforoosh, W. Asghar, and F. Jamali, "Adverse effects of nonsteroidal antiinflammatory drugs: An update of gastrointestinal, cardiovascular and renal complications," J. Pharm. Pharm. Sci., vol. 16, no. 5, pp. 821-847, 2013, doi: 10.18433/j3vw2f.

[12].Elfahmi, H. J. Woerdenbag, and O. Kayser, "Jamu: Indonesian traditional herbal medicine towards rational phytopharmacological use," J. Herb. Med., vol. 4, no. 2, pp. 51-73, 2014, doi: 10.1016/j.hermed.2014.01.002.

[13].S. Mussarat, N. M. Abdel-Salam, A. Tariq, S. M. Wazir, R. Ullah, and M. Adnan, "Use of ethnomedicinal plants by the people living around indus river," Evidence-based Complement. Altern. Med., vol. 2014, no. i, pp. 1-14, 2014, doi: 10.1155/2014/212634.

[14].G. Brahmachari, Discovery and Development of Anti-Inflammatory Agents from Natural Products. Amsterdam: Mica Haley, 2018.

[15].J. Lorenzo, mark c Horowitz, Y. Choi, T. Hirosh, and G. Schiett, "Osteoimmunology: Interactions of the immune and skeletal systems," Osteoimmunology Interact. immune Skelet. Syst., pp. 103-119, 2016, doi: 10.1016/B978-0-12-800571-2/00021-9.

[16].M. Chen et al., "Chemical components, pharmacological properties, and nanoparticulate delivery systems of Brucea javanica," Int. J. Nanomedicine, vol. 8, pp. 85-92, 2012, doi: 10.2147/IJN.S31636.

[17].S. H. Dong et al., "Chemical constituents from Brucea javanica," Phytochemistry, vol. 85, pp. 175184, 2013, doi: 10.1016/j.phytochem.2012.08.018.

[18].X. qi Yu, X. yue Shang, X. xiao Huang, G. dong Yao, and S. jiang Song, "Brusatol: A potential antitumor quassinoid from Brucea javanica," Chinese Herb. Med., vol. 12, no. 4, pp. 359-366, 2020, doi: 10.1016/j.chmed.2020.05.007.

[19].S. Ma et al., "Intravenous microemulsion of docetaxel containing an anti-tumor synergistic ingredient (Brucea javanica oil): Formulation and pharmacokinetics," Int. J. Nanomedicine, vol. 8, pp. 40454052, 2013, doi: 10.2147/IJN.S47956.

[20].A. NoorShahida, T. W. Wong, and C. Y. Choo, "Hypoglycemic effect of quassinoids from Brucea javanica (L.) Merr (Simaroubaceae) seeds,” J. Ethnopharmacol., vol. 124, no. 3, pp. 586-591, 2009, doi: 10.1016/j.jep.2009.04.058.

[21].I. Ifora, W. Kardela, and H. Y. M. Yora, "Uji Aktivitas Antikolesterol Ekstrak Etanol Buah Malur ( Brucea Javanica ( L .) Merr ) terhadap Mencit Putih Jantan Hiperkolesterolemia,” J. Farm. Higea, vol. 11, no. 1, pp. 2-3, 2019.

[22].C. Bardella, A. R. Al-Shammari, L. Soares, I. Tomlinson, E. O’Neill, and F. G. Szele, "The role of inflammation in subventricular zone cancer," Prog. Neurobiol., vol. 170, no. 2010, pp. 37-52, 2018, doi: 10.1016/j.pneurobio.2018.04.007.

[23].N. Bowker et al., "Meta-analysis investigating the role of interleukin-6 mediated inflammation in type 2 diabetes," EBioMedicine, vol. 61, p. 103062, 2020, doi: 10.1016/j.ebiom.2020.103062.

[24].C. G. Qiu, Z. Naing, and Z. Y. Han, "TCTAP A-134 Role of Hypercholesterolemia and Inflammation in No/Slow Reflow During Elective PCI in ACS patients," J. Am. Coll. Cardiol., vol. 63, no. 12, p. S39, 2014, doi: 10.1016/j.jacc.2014.02.162.

[25].Y. F. Huang et al., "Therapeutic effect of Brucea javanica oil emulsion on experimental Crohn's disease in rats: Involvement of TLR4/ NF-кB signaling pathway," Biomed. Pharmacother., vol. 114, no. February, p. 108766, 2019, doi: 10.1016/j.biopha.2019.108766.

[26].J. Yang et al., "Anti-inflammatory activity of ethyl acetate fraction of the seeds of Brucea Javanica," J. Ethnopharmacol., vol. 147, no. 2, pp. 442-446, 2013, doi: 10.1016/j.jep.2013.03.034.

[27].J. Zhou et al., "Brusatol ameliorates 2, 4, 6-trinitrobenzenesulfonic acid-induced experimental colitis in rats: Involvement of NF-кB pathway and NLRP3 inflammasome," Int. Immunopharmacol., vol. 64, no. June, pp. 264-274, 2018, doi: 10.1016/j.intimp.2018.09.008.

[28].Ifora, D. Haryani, and R. Abdillah, "Anti-Inflammatory Activity and Cyclooxygenase-2 Inhibition of 


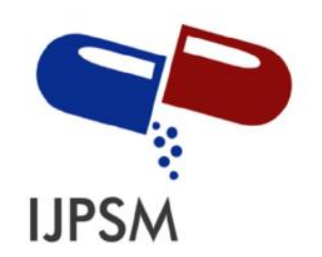

Sisi Mustika et al, Int. Journal of Pharmaceutical Sciences and Medicine (IJPSM),

Vol.6 Issue. 9, September- 2021, pg. 1-7

ISSN: 2519-9889

Impact Factor: 3.426

Ethanol Extract from Malur Leaves ( Brucea javanica ( L .) Merr ),” J. Pharm. Sci., vol. 3, no. 1, pp. 7-13, 2020.

[29].J. Magdalon et al., "Oral administration of oleic or linoleic acids modulates the production of inflammatory mediators by rat macrophages," Lipids, vol. 47, no. 8, pp. 803-812, 2012, doi: 10.1007/s11745-012-3687-9.

[30].M. J. A. S. O.Z. Ameer, I.M. Salman, "cardiovascular activity of the nbutanol fraction of the methanolextract," vol. 43, no. 2, pp. 186-194, 2014, doi: 10.1590/S0100-879X2010005000002. 